\title{
Community Banking Services and the Fight Against Poverty in Ghana: Could this be the Panacea for Sustainable Community Development?
}

\author{
Ezekiel Nibenong Seudib and Issifu A. Amadu
}

\begin{abstract}
The general objective of this study was to assess the effects of a cooperative society on the livelihood of farmers in Ghana. The convenience and simple random sampling methods of data collection were used to select two hundred (200) out of two thousand and seventeen $(2,017)$ farmers who were clients of the study institution, and four staff at the cooperative studied for the research. The major instruments that were used comprised a structured questionnaire in both cases and an interview schedule for only those farmers who were unable to read. The data collected were analysed using the Statistical Product and Service Solution' version 20 (SPSS) and Microsoft excel. The findings from the research indicate that services of the cooperative have led to significant improvements in the livelihood of the farmers. The conclusion reached was that the farmers were empowered by loans which enabled them acquire farms inputs, implements and other forms of assets. On the basis of these findings, it was recommended that establishment of financial cooperatives in farming communities should be encouraged by the government, district assemblies and community leaders to enable farmers improve on their productive entrepreneurial activities in agriculture to boost rural household incomes which implicitly fights rural poverty and improves national development.
\end{abstract}

Index Terms - Community banking; Community development; community cooperatives; Livelihoods; poverty.

\section{INTRODUCTION}

Ghana's economy has a lot of potential for growth and development. Abundant natural resources of the country remain largely un-explored; especially, the vast uncultivated land. This has to be harnessed to the fullest for the general well-being of Ghanaians in the world economy. Perhaps, one important way to achieve this goal is through the encouragement of cooperative movements [5]. Reference [32] posits that if current agricultural trends continue, by the year 2020 sub-Saharan Africa's food shortage will increase twenty times to 250 million tons. That could lead to poverty, malnutrition and hunger, and the inability of farmers to take basic but crucial social responsibilities such as paying for their wards' school fees, medical bills etc.

Ghana's quest to harness state resources to improve the general economic wellbeing of its people has been daunting in recent times. The gap between economic growth and the actual economic well-being of the populace is yawning. It has been argued in global development circles that Africa's impoverished populations that are largely engaged in subsistence agriculture can only escape poverty through financial arrangements that support communities to sustain their productive activities. In an attempt to relieve some of these potential problems, several sources of credit have been made available to communities; particularly financial cooperatives. The hope is that, in the long-term, access to credit will enable the rural farmers to invest in agricultural and non-agricultural productive assets by adopting appropriate farming methods to increase productivity in agriculture whiles managing environmental degradation. Ghana's rural poor dwellers are among the world's number 1 billion poorest. Financial initiatives such as community cooperatives are certainly a welcome option to get rural farmers and their households out of poverty. Cooperatives are a channel of credit to farmers and other entrepreneurial individuals for productive ventures in the local economy. A research by [41] revealed that community development has seen a higher contribution of cooperatives societies through self-help effort in areas such as schools' rehabilitation, road construction and other community projects (mosques construction, rehabilitation, donation of books and medicine to schools and community clinic, financial and material assistance to disabled people).

A cooperative society is defined as an autonomous association of persons who unite voluntarily to meet their common economic, social needs and aspiration through a jointly owned and democratically controlled enterprise [25]. Reference [16] also indicated that, cooperative society is an organization of group of people with collective responsibilities and thoughts for the development of needy, especially under privileged.

The Ghanaian government since independence in 1957 has made several attempts to improve agriculture in an effort to increase living standards of the people in the country, especially those who reside in the rural areas (farmers). Access by farmers to affordable and less cumbersome financial services has been the bane for the rapid growth of the agricultural sector in Ghana. The lack of financial literacy skills by farmers in rural communities hinders their ability to access credit from commercial banks. For this reason, cooperative societies or credit unions are oftentimes referred as potential source of financial leverage to country level agrobased activities.

In addition, some of the banks also consider the scale of the farm of a farmer before granting a loan request, this makes it difficult for peasant farmers to access loans from them. The most upsetting problem that farmers do face is the high interest rates charged by financial institutions for the use of their money. It is very difficult in contemporary times for

Published on July 22, 2020.

Ezekiel Nibenong Seudib, BACCSOD Ltd, Ghana.

Issifu A. Amadu, University for Development Studies, Ghana.

(corresponding e-mail: amedissifu@ ${ }^{\circledR}$ gmail.com) 
farmers to benefit from state incentives to sustain their agrarian activities, and for this reason they are obliged to seek other avenues such as rural and commercial banks that impose very high interest rates on money for risky ventures including farming. Many of the farmers who eventually accessed loans from them ended up selling their farmlands or properties in order to payback the loans.

With reference to the Chronicle paper (February 2008), Professor George Gyan-Baffour, the then Deputy minister of Finance and Economic Planning, indicated that high interest rates charged by universal banks as well as savings and loans companies were killing businesses in the country; especially small and medium enterprises. He further intimated that trends in lending and borrowing rates were still high since it was affecting the growth of businesses in the country. According to him, the problem of high interest rates was an impediment on the economy since it compels more businesses to close down [44]. According to the secretary of Badu (the study area) maize production and marketing by members of the cooperative has been on the ascendency; beginning from 1172 bags, 1349 bags, 2821 bags, 1449 bags, 1694 bags and 1530 bags of maize were sold in the open market in January, February, March, April, May and June respectively in the year 2014; this sums up to 10,015 bags for just half a year, neglecting those that were reserved by farmers for their own consumption and others that were not vended in the maize market. Even with that many of these farmers do cultivate other crops in addition, for example; yam, pepper, beans, cassava etc. This calls for the need to ponder on how and where these farmers get their funding and support from.

Meanwhile [47] opines that the upsurge in the call for financial services has resulted in alteration of cooperative societies as a factor in financial, social science and economic disciplines in such a way that both international and local establishments have continued to explore the best modalities in the application of cooperative concept to virtually all field of the economic. This probably has warranted the proclamation of 2005 and 2012 as microcredit year and cooperatives year respectively by the United Nations General Assembly.

This research therefore sought to investigate the effects of Brong Ahafo Catholic Cooperative Society for Development (BACCSOD) on the livelihood of farmers in their catchment area in Ghana. This paper presents some basic empirical evidence that poverty in Ghana's rural communities can be tackled sustainably through such community empowered initiatives such as cooperative financial schemes that specifically targets the rural folk who oftentimes are not financially informed.

\section{A. Study objective and hypotheses}

The general objective of the study was to examine the effects of a selected cooperative society on the livelihood of farmers. It is understood that co-operative societies offer valuable financial leverage to rural farmers and that constitutes a big boost to national development of subSaharan countries whose economies are largely agrarian. Specifically, the study focused on the effect of co-operative society on the overall development of communities. The study was guided by the following hypotheses:
Null hypothesis (HO): cooperative societies do not promote community development

Alternative hypothesis (H1): 'cooperative societies promote community development

\section{THEORETICAL PERSPECTIVES}

\section{A. Physiognomies of Rural and Community Finance}

Cooperatives societies are located everywhere, some in the urban areas and with most of them in the rural areas. Cooperatives are dominant in the rural areas because these areas are generally ignored by the formal financial market for financial inclusion and this call for the need to assess the role of cooperative in rural finance where majority of the people do not enjoy the services of the formal financial providers. According to [51], formal financial providers neglect the rural areas because they find it too costly to operate in such areas where they are anticipating low level of economic return in the form of profit. It is equally noted that formal financial providers are less in the semi-urban areas and rural areas for fear of high risk, lack of adequate collateral and cost of transactions. For a fact, cooperatives enjoy their services in these areas [46]. This could be the reason that cooperative societies understand the nature of the rural finance and environment much better and are able to roll out products that directly meet the needs of the rural people.

Rural finance is the provision of sustainable financial services in rural areas such that the services support different levels of income of rural dwellers [58] so that they are able to understand the services and use and benefit from them directly and easily. This is prudent as rural dwellers get to increase productivity and income through goods and services trade, through access to finance in the rural area [25]. This has the possibility of reducing poverty and for that matter improves the livelihood and standard of living of the people. Any sector whether formal, semiformal or informal can render financial service to the rural areas, but to success in it, services should be supportive to the income of the rural dwellers such that they lose interest in the other financial sectors because of the low financial literacy among dwellers of these areas.

Reference [8] recognized informal rural finance providers' in Nigeria to composed of: trade and input supply financing, nongovernmental organisations (NGOs), cooperative societies, esusus, money lenders, families and friends. Similarly, [42] testified that the informal finance providers in Uganda were made of cooperative and credit societies, commercial firms' employers, NGO, money lenders, government credit scheme, relatives and friends. Cooperatives are highly acceptable to the rural dwellers as it is easier and faster medium of sourcing for credit as juxtapose to the microfinance banks and commercial banks [24]. Cooperative societies as part of the rural finance providers is a cost-effective model for providing financial services to those segments of the population that have little or no access to formal financial services [25], and definitely that is the reason why they are able to survive.

The impact of cooperatives to the rural economy and for financial inclusion cannot be over emphasized. A living 
example is that, in developing countries, about $70 \%$ of adults have no access to financial service and this could be higher in rural areas, while about $90 \%$ of the rural sector financial needs are satisfied by informal rural finance providers[39], [47]. Consequently, the cooperative societies can be regarded as financial providers for entrepreneurs in the rural areas, while the individual organisation for rural finance include money collectors, friends, family, and money lenders [20],[45].

\section{B. Evolution of micro finance and cooperative society}

Microfinance is considered by [39] as institutions which attempt to improve access to small deposits and small loans for poor households neglected by banks while [25] also define cooperatives as associations which are made of independent people who unite voluntarily to established, owned and control it democratically to meet their cultural, social and economic needs.

According to Ghosh [24], recent cooperatives began in 1904 in British India when the cooperative societies act was enacted. The aim of the cooperatives at beginning was to provide affordable credit to the farmers. Going forward, cooperatives were introduced into Russia in mid-19th century from Germany [25]. Though the precise year was not mentioned. Reference [35] reported that by 1883 , there were approximately 981 cooperatives in Russia. Those in rural areas are often named credit cooperatives while those within the urban centres are normally labelled as credit union.

Reference [59] also asserts that the operation of microcredit and microfinance first became prominent in 1970s and goes further to state that the Badan Kredit Desa village banks and the Bank Dagang Bali in Indonesia, the Self-Employed Women's Association, Women's Cooperative Bank in India, the early ACCIÓN affiliates in Latin America, and various NGOs, credit unions, and cooperatives in a variety of countries were the few, scattered, early pioneers which led the way in developing the financial systems approach to microfinance. Robinson (2001) posits that from $1950 \mathrm{~s}$ through to the $1970 \mathrm{~s}$, the provision of financial services by donors or governments was mainly in the form of subsidised rural credit programmes. According to [53], from the 1950s and proliferating in the 1960s and 1970s, these programmes were usually accompanied by high loan defaults, high losses, and a general inability to reach poor rural households. A 1995 worldwide survey of 206 microfinance institutions that had opened in or before 1992 found that only 7 percent had been in operation before 1960; 48 percent had been founded between 1980 and 1989. In the 1980s it became clear for the first time that microfinance could provide large-scale outreach profitably. The Microcredit Summit which was launched in 1997 reinforced the importance of microfinance and hence brought a lot of improvement to the field. The Summit aimed to reach 175 million of the world's poorest families, especially the women of those families with credit for the self-employed and other financial and business services by the end of 2015 [8]. Analysis from the February 2000 Micro Banking Bulletin database indicated financial results from 104 microfinance institutions; of these, 60 were fully financially sustainable. This really showed a gradual successful growth of the industry.
Certainly, microfinance concept has been a topical in the development discourse in Ghana. Reference [7] indicated that it has always been common practice for people to save and/or take small loans from individuals and groups within the context of self-help in order to engage in small retail businesses or farming ventures. Anecdotal evidence suggests that the first credit union in Africa was probably established in Northern Ghana in 1955 by the Canadian Catholic missionaries that were there at the time". To support that, [6] indicated that the first credit union in Africa was formed at Jirapa in the North - West of Ghana now the Upper West Region by Rev. Father John McNulty an Irish Canadian[11]. However, 'Susu', which is one of the current microfinance schemes in Ghana, is thought to have originated from Nigeria and spread to Ghana from the early 1900s [7].

Meanwhile, [47] stated that the survival of cooperative societies in any country depends largely on the overall political and economic environment of such nation because cooperative exists within the wider economy of the particular country where it operates. The enactment of PNDC Law 328 in 1991 allowed the establishment of different types of nonbanking financial institutions including savings and loans companies, finance houses, and credit unions etc. under micro finance [7]. According to [7], that led to the three broad types of microfinance institutions operating in Ghana, which include:

- Formal suppliers of microfinance (i.e. rural and community banks, savings and loans companies, commercial banks)

- Semi-formal suppliers of microfinance (i.e. credit unions, financial nongovernmental organisations (FNGOs), and cooperatives)

- Informal suppliers of microfinance (e.g. 'susu' collectors and clubs, rotating and accumulating savings and credit associations, traders, money lenders and other individuals).

The evolution of microfinance makes it clear that cooperative societies are examples of semi-formal microfinance types of microfinance institutions in Ghana.

\section{Cooperative societies}

According to [13],[14],[15], Cooperatives are thought to represent an effective institution for solving the problems that small farmers face in developing countries. While [55] defines cooperatives as financial institutions that are owned and controlled by the members, providing credit and savings services to the members within the community [55], [1] equally saw cooperatives to be voluntary associations that are owned by the members, managed by themselves and democratically controlled within a particular location. Similarly, [25] explain that cooperatives are associations which are comprised of independent people who unite voluntarily to establish, own and control them democratically to meet their cultural, social and economic needs. In the same vein, [46] opines that cooperative societies are privately structured association of people of like minds who unite to mobilizes fund and grant loans to themselves. Furthermore, Cooperative societies, are also known as credit cooperatives, financial cooperatives, savings \& credit cooperatives, and credit unions which could be members sponsored, government-sponsored or programme sponsored [24],[57]. 
The operation of cooperatives provides an opportunity for gathering of financial resources of members limited funds in order to meet the developmental needs of members [58]. Cooperative societies are community based, self-funded and self-controlled financial institutions which welcome other people who share in their vision [57]. A school of thought also saw cooperative as one with variety of financial provisions calculated to entice the poor as either saver and/or borrower [39] for a mutual benefit as such people eventually become members [4], [39]. The success story of cooperatives is eminent for a fact that cooperatives have been the forerunner of development related interventions that aim at poverty alleviation for the needy in the rural communities [58]. The good news is that rural dwellers are often gratified with the little financial services that are usually rendered by cooperatives because they also take part in the running of the associations through decisions taken at their annual general meetings. Consequently, Cooperative gives room to low income earners to get non-financial and financial services that are parceled in a way that enable people who are deprived of financial services of the formal sector, to access saving schemes, loans and other services that can empower them with working capital and means for income generation [42].

In Ghana cooperatives are never indigenous institutions but were introduced by the colonial masters. The British Colonial government, in its effort to get the best quality cocoa beans from Gold Coast (now Ghana) set up a group farm venture in 1928 through its Department of Agriculture at a small village called 'Atasomanso', near Kumasi in the Ashanti Region of Ghana. This led to the formation of several cooperative cocoa societies throughout the forest zone of the country. According to Isaac [48], the success of the cocoa cooperatives led to the formation of other agricultural cooperatives as well as industrial, services and financial cooperatives. The Cooperative Societies Ordinance No. 4 of 1931 set the legal framework of how different types of cooperatives should exist in Ghana and up till date it is known as "Nwoboa" and "Kogtaa" among farmers in the "Akan' and the 'Dagaare' communities of Ghana. The cooperative ordinance as a framework for cooperatives, laid down the rights and liabilities of society members.

Cooperative society industry is now grown to a larger extend and can be found in many areas of life either than the cocoa sector of agriculture originally noted.

\section{Cooperative Practice}

The fact that many of the cooperative products are often tailored to meet the rural dwellers needs, some people think that cooperatives are mend for the poor. It is on this note that [47] stressed that there is a high demand for cooperatives all over the world and that cooperative services are not limited to rural societies alone but is applicable to both the developed and developing countries. It is also known that, cooperative members stem from females, males, displaced persons, head of households, retrenched workers, micro entrepreneurs and small farmers, which falls into four poverty levels: the vulnerable non-poor, moderately poor, extremely poor and the destitute. Like other countries, in Ghana all manner of people both poor and rich can be found on the list of the membership of cooperatives. Cooperatives are not restricted to any group of people, but it is all about the availability of financial services that are helpful to the poor people no matter wherever they live or what they do to earn a living, it is cooperatives aim to offer financial services that emancipate the rural dwellers from poverty for a better standard of living. Therefore, cooperatives are established to mobilise savings from members which is eventually based on to grant access to loan and other opportunities from which wealth can be created [47]. Cooperatives are strategically structured for poverty mitigation for rural people [1], and they are usually based on values such as equity, self-help, equality, selfresponsibility, solidarity and democracy among members [25].

It is mentioned that the inability of governments and the markets to render social services and goods efficiently to the general populate more especially the rural settlement led to the formation and spread of cooperatives. The existence of employee cooperatives in some institutions shrink the burden of loan request from their employers and also serve as a common platform for owning household equipment and other assets at a reduced interest rate spread over a particular period of time [46]. Since cooperatives are not basically formed to make profit, they are able to balance the economic necessities of members with profitability of the programme [47]. Hence Most experts in cooperatives explain that savings deposits added an important dimension of risk reduction to the participants as members turns to support one another in their work, business etc. for a formation of a greater force for price negotiation or other benefits at large. Cooperatives are based on the members' ideology and need; hence there is a need to reduce government intervention in cooperatives to the barest minimum especially in areas where financial demand is high with no availability of formal financial services [47].

\section{E. Capital formation the role of cooperative societies}

According to Professor Nurkse, "The meaning of 'capital formation' is that society does not apply the whole of its current productive activity to the needs and desires of immediate consumption, but directs a part of it to the tools and making of capital goods: tools and instruments, machines and transport facilities, plant and equipment; all the various forms of real capital that can so greatly increase the efficacy of productive effort. The essence of the process, then, is the diversion of a part of society's currently available resources to the purpose of increasing the stock of capital goods so as to make possible an expansion of consumable output in the future." [27].

Cooperatives are formed to gather money and resources from individuals for investment as well as for the purpose of helping their members by way of giving of loans and other assistance to them at good rate. Reference [27] explains that in rural areas cooperatives provide loans to the farmers for the purchase of seeds, fertilizers and cattle. Loans that are usually given to cooperative members are gotten from the savings of the members at the cooperative. The mobilisation of savings is fundamental principle of cooperative societies. When individuals postpone their consumption to the future, they save their wealth for further production. If all individuals save this way, the aggregate savings will be increase which can be used for investment purposes in real capital assets like machines, tools, plants, roads, canals, fertilizers, seeds, etc." [27]. In effect this is how cooperatives societies normally 
aggregate capital for their daily activities of meeting their members' needs. Reference [26] points out that services that are provided by formal financial system, cover about $35 \%$ of the population, which is economically active citizens of Nigerian, while the remaining $65 \%$ are left out. Cooperative societies there have to cover the remaining population, which according to [26], cooperatives handle this by simply entreating members to get committed to saving and agreed on amount for a fixed period of time which is a way of equipping members with capital through loans. Elaborating on it further [28] opined that many members have their businesses yielding surpluses that are about $15.7 \%$ of their net income because they have access to cheap loan which is one of the cooperative styles of capital empowerment. A documentation on the usage of money from cooperatives by [68] emphasised that members used loan to buy motorcycle in Rwanda which help to increase their income and for that matter their capital. Adding to that, while [17] recognised that member through cooperatives were able to successfully established small scale businesses, health care centres, food processing plants and poultry farms, [20] equally realised that members were able to buy tools than non-members and invest in small assets more than their counterparts in their market sites. As though people join together to solve their problems collectively, they end up forming capital either knowingly or unknowingly out of which they get empowered for combating their calamities.

\section{F. Community development, the role of cooperative societies}

In times and seasons like ours, where community developers are increasingly interested in alternative models for local businesses that will be both responsive to community needs as well as stimulate local economic growth, Reference [65] proposed that the cooperative form of business is an obvious choice. He further indicated that, cooperatives have the potential to foster economic growth at the community and regional levels, building on the spirit of cooperation that is already prevalent in rural areas. The is a popular saying that "unity is strength" but when it comes to community development the scenario here is "unity is development". Community needs are usually cost intensive which cannot be provided by an individual but together it can be done. Taking this for an example, an averagely large community cannot be swept or cleaned by an individual using one week, but with the use of communal labour which is under the spirit of unity, such community could be cleaned in a day or two. Cooperative is basically a formal form of unity which can be leveraged on for all manner of community development. On that note, [58] stated that cooperatives are the most important forms of involvement in financial markets accessible to the Tanzanians rural communities, of which [40] found a significant helpful outcome of cooperative loan on increase in salaries, establishment of business, increase in salaries and employment.

In addition, [65] that, with local ownership and control, and net profits distributed to those who use the cooperatives, cooperatives are considered by some people to be an ideal model for local economic and for that matter community development. The structure and objectives of cooperatives compel community members to behave differently in their communities than businesses with other organisational structures. In line with this [65] explained that, the fact that cooperatives or any actual legal business structures are largely ignored in both community development theory and practice may reflect either a lack of detailed knowledge about business structures or an erroneous assumption that their differences (beyond local ownership and control) are trivial in a community development context. In effect the role of cooperatives in communities' development cannot be over emphasized. Cooperatives in reality are the way to easy and sustainable community development. A Community Development Co-operative is the basis for one community's economic empowerment and sustainability which has become extremely critical with current economic woes.

Consequently, Cooperatives do combine resources of people into largely more viable and economically competitive units, development tools and should therefore promote both social empowerment and economic goals of the communities in which they exist.

\section{G. Community Development Approaches by cooperatives}

In the narrowest sense, community development involves increasing the number or quality of jobs so that individual and aggregate income expands [62]. It is an undisputable fact that a community with many cooperatives will have many jobs opportunities and of course will have all or many of its people employed. This automatically will lead to a rapid development of such community.

Additionally, [65] stated that from the local development perspective, a critical feature of the cooperative model is that it can be owned and controlled by community residents. Therefore, a cooperative is more likely to be interested in promoting community growth than an investor-owned firm controlled by non-local investors. Eventually, if community residents control the firm, they can ensure that their own objectives are met, and not those of people who live elsewhere.

Financial Advantages: Cooperatives are eligible to apply for loans and grants from a number of federal and state agencies designed to support cooperatives development [65]. These can provide significant sources of low-cost start-up and operational funds for the cooperative business. In addition, other non-governmental financial intermediaries such as cooperative banks provide relatively low-cost loans to cooperatives. Cooperatives can also benefit from significant tax advantages. Finally, cooperatives may also be able to take advantage of lower labor costs, as members may be willing to contribute labor instead of capital as a form of investment in their business [65]. This put cooperatives in the right financial position to contribute toward communities' development.

\section{H. Cooperative society and better communities' livelihood}

The recognition of co-operatives as self-help organizations with capacity to improve peoples' livelihoods and wellbeing is global and widespread among institutions. Elaborating further, [61] conducted a study in Ghana and found that the absence of social protection schemes in the informal sector of the country makes people in the rural and the urban areas to look up to cooperatives societies as a source of solidarity in times of need. The United Nations, in 1994, estimated that cooperatives provide livelihood security for three billion people. In effect, co-operatives seek to harness and exploit 
collective latent and potential resources available to members that would have hitherto remained unexploited and ineffective [22].

According to [63] cooperatives are considered to have immense potential to deliver goods and services in areas where both the public and the private sector have failed. In line with cooperatives role in sustaining communities' livelihood [22] said that cooperatives in Canada have contributed to building sustainable livelihoods by providing needed services, providing access to basic financial services in the community and enabling members to access and benefit from markets. According to him, that has resulted in members' been productive in agriculture, small and medium enterprises and stable community development. In effect cooperative societies have the potential of making live wealth living for communities' members, wherever they exist. Also, [64] used qualitative data from 11 African countries to define the impact of cooperatives on poverty reduction among households and established that the program enables members to accumulate savings. Similarly, [20] established that $23 \%$ of clients subjected their earnings from the cooperative on their household education. While [33] noticed that from a sample of 49 dwellers of rural areas who applied for bank loan, only $10.20 \%$ were fruitful juxtaposed to $98.09 \%$ of applicants who successfully obtained loan from the cooperative society. Though the research was not precise if the study sites are rural, urban or both, it is significant to know that loan accessibility rate at cooperative societies is very high. The fact that cooperative societies are supportive to rural dwellers, [57] in a study denoted that cooperative members were eager to save and that $49 \%$ really save to provide security against theft, $28 \%$ to avoid useless expenses, while $15 \%$ save against fire, $13 \%$ save in order to have access to loan. It is obvious that cooperatives are helpful in ensuring that rural community people enjoy a better living by way of providing them with a secure medium of saving their money, give them financial education, business advice, enable them to have access to all manner of financial aids thereby improving upon their livelihood and standard of living in general. Reference [57] concluded that savings deposits added an important dimension of risk reduction to the participants, and that include protection from theft. On that note [1] established that $70 \%$ of the members' experience improvement in their standard of living, 20\% reported reduction while $10 \%$ had stagnation.

Furthermore, [16] saw cooperative societies as groups of people with collective responsibilities and thoughts for the development of the needy, especially under privileged. He further indicated that, cooperatives help in the development of agriculture, banking, credit, agro-processing, storage, marketing, dairy, fishing, housing and its network covers 85 percent of rural households. It occupies a key position in agricultural development with support in resource and input use, harvesting of water resources, marketing channels, storage facilities, distribution channels, value addition, market information and a regular monitoring network system [16]. By and large, cooperatives (except a few large ones) are "local institutions", addressing "local needs", employing "local talent", and led by "local leaders" [16]. Consequently, it has been established that beneficiaries of loans from cooperatives get above the poverty level as such loans to members are often cheaper and came as at when needed. Cooperatives should therefore be encouraged to operate in every community of a country, more especially in the deprived communities.

\section{Co-operative performance measurement}

It is very important to measure the performance of cooperatives; this will enable members to know the state of their interest in the cooperative. For people who are looking for a cooperative to join will usually make their choice based on the performance results of a cooperative. On this note a question which will normally be asked by people is; which cooperative perform better?

However with performance measure as key, [33] talking about a milk cooperative performance said that financial ratios were usually used to provide objective and readily available measures of performance-return on equity, return on assets, return on operating capital (the sum of fixed assets and working capital), net margins on sales, and net margins per hundredweight of milk, etc. they further explained "while worthwhile benchmarks, none would yield an unequivocal answer to the performance question". This is because if one is faced with the choice of which cooperative to invest in with the above methods as the bases for choice making, it would be a problem particularly in the case where the two companies have greater returns on their equity.

In order to avoid the above-mentioned difficulty, [33] included in their report using a new method for evaluating business performance to measure and compare U.S. dairy cooperatives, a method which was proposed by [24] and modified to suit cooperatives. This indeed is a method which can help cooperatives to effectively and efficiently measure their performance. The new tool uses an "extra value" approach. It accounts for the total cost of operations including cost on equity and measures performance in terms of earnings generated, net of this total cost. Extra value can be calculated using the information commonly found on any firm's financial statements (except for the interest rate on equity which has to be imputed).

Extra value $=$ Net operating margin $($ before tax $)$ - Interest on equity

Where:

\section{Net operating margin}

$($ Before tax $)=$ Opera ting margin + Interest income -

Interest expenses + other income-Other expenses, and

\section{Interest on equity $=($ Member or stockholder equity- Investment in other firms) $x$ Interest rate.}

Any patronage or investment income is excluded from the net operating margin as these are not the results of the cooperative's own operations and should not play a part in measuring operating performance. Likewise, investment in other firms is removed from the cooperative's assets and the corresponding amount is subtracted from members' or stockholders' equity. This way, extra value captures the cooperative's operating performance and not the performance of other firms in which the cooperative invests. Ideally, the interest on equity is a value imputed from the cooperative's own opportunity cost of capital. The appropriate rate is cooperative-specific [33],[34]. In effect cooperatives can 
measure their performance using the extra value method or any other suitable performance measure tool.

\section{J. Challenges facing co-operatives}

Co-operatives generally face various challenges ranging from accounts receivable, agricultural economy, competition, consolidation, technology, government regulations, government programmes, increasing costs, low commodity prices, operational obstacles, adverse and unpredictable weather changes, low margins to poorly developed market research and market information. In exploring the challenges of cooperatives [38] identified one of them to be the challenge of co-op governance, in that he explains that by way of the equality principle, of the constitution of a fully empowered general assembly, of the periodic election of administrators, the democratic powers and duties of the cooperative are firmly established on the members. In a circumstance like this everyone becomes his own boss making it difficult for on time and quality decision making for cooperatives. This is because in times of decision making all the cooperatives members will need to meet before conclusions on what to do about a situation can be taken, which in no doubt will always cause a delay in a cooperative decision making. Meanwhile [10] also stated that lack of democracy resulting from excessive concern over business efficiency has caused lack of co-operative identity. Reference further stated that as a result of competition, market forces meeting fast moving orders and supplies, it has manifested that top down management has taken root instead of peoples' democracy. The focus on business performance has drastically reduced member participation in decision-making and as a result, members have felt remote from their co-operative; hence, sacrificing the members' traditional nature of feeling strongly related to the co-operative [10]. In the light of this management of cooperatives in many instances would normally get confused as to whether to concentrate on the cooperative members and lose their customers or the vice versa. But beyond everything, taking the members and the managers of a cooperative through proper training and development can be a good solution.

\section{K. Why cooperatives easily fail some}

When discussing the failure of cooperatives in Africa and elsewhere, one needs to shed some lights on the issue. There exist practitioners who pretend that the reason for failure of cooperatives in the African context is the inherent disequilibrium in their annual balance sheet, between the financial equities and reserves (shares, savings, and nondivided earnings), and their capital (loans demand and cash). In short, the lack of financial resources needed to their functioning. Meanwhile, in the reality the failure of cooperatives in Africa or elsewhere goes beyond just lack of financial resources for their operations.

Some the challenges cooperatives face includes negative effects of group size with collective action. This is not to say that collective action has no benefits. To respond to this Joan and [16] argue that the potential advantages of collective action critically depend on the possibility of distributing the benefits from cooperation in ways that pay all potential partners to cooperate. According to them that is the wellknown free-rider problem. Individual rewards depend on the action contributed by other group members as well as on one's own. If so, the relationship between the number of society members and efficiency follows an inverted $U$ pattern, implying that an optimum size exists for cooperatives [49]. This is to say that as the number of people in a cooperative increases the free rider problems begin to pop up, that is some people begin to hide behind (i.e. refusing to perform their duties) to enjoy the profit (i.e. the sweat of others) of the cooperative. As this continuous, eventually hard-working member of the cooperative could begin to also decline the execution of their duties leading to the general failure of the cooperative in achieving its objectives.

To mitigate problems of this kind, [49] and [3] (for example, pointed to entry and exit rules influencing behaviour and minimising free-rider problems, thereby improving the efficiency of collective action even in large groups. This is to say that as people come in as members of a cooperative, there should be rules making it possible to sack inactive members of the cooperative in order to make the society effective and productive.

\section{Are cooperatives still pertinent for growth?}

The evolution of cooperatives shows that they have been in existence for a very long time. Their impact for some time now has been felt in various parts of the world economy. To starts with, [2] said that several categories of people such as rural inhabitants, poor people and uneducated people are not served by formal financial institutions in developing countries making it significant for cooperative to come in and bridge the gap. Affirming that, [43] indicated that delivery of banking services in developing nations reaches less than $20 \%$ of the population. The situation of Ghana may even be worse than that, implying that cooperatives financial institutions and other informal institutions need to encourage to intensify their operations to cover the unserved and underserved population for financial inclusion. Studying on the impact level of cooperatives on a general perspective [52] demonstrated that cooperatives have stronger tendency to foster ties of social capital than other organizational forms present in the market and this in itself testifies to their ability to enhance market exchanges through better contract enforcement and lowering of transaction costs. Observing the situation from the agricultural point, [60] made mentioned that Agricultural cooperatives in particular help individual farmers resist market pressures from their downstream partners giving them an opportunity to reduce cost of transaction by jointly performing activities related to marketing and/or processing of their produce. Cooperatives also have a character formation ability which according to [53] appears to be especially relevant to societies characterized by a democratic deficit owing to their inclusive governance model and their insisting that every member counts.

Traditional forms of cooperation involved community members voluntarily pooling financial resources through an association of people with the common objectives of mobilizing resources, especially finance, and distributing them to members on rotational basis [36]. Cooperative system tries to enforce financial equity in that people with low income generation ability are able to access loan and enter into ventures which in otherwise their funds could not have been enough to venture. Further elaborating on the 
importance of cooperatives [62] said that in recent era where many people feel powerless to change their lives, cooperatives represent a strong, vibrant, and viable economic alternative. Cooperatives are formed to meet peoples' mutual needs. They are based on the powerful idea that together; a group of people can achieve goals that none of them could achieve alone. They provide a unique tool for achieving one or more economic goals in an increasingly competitive global economy [59]. Above all, access to finance in rural areas creates opportunity for rural dwellers to increase their productivity and income through purchase of goods and services with possibility of reduction in poverty and improvement in standard of living [25]. The ability of any cooperative society to affect the members positively at household and enterprise level signifies an improvement in standard of living and better economic condition of the participants [18],[19],[46]. Reference [56] executed analysis on changes in income reported due to cooperative support unveiled that, $25 \%$ of households that were originally below poverty line exited poverty after joining an informal. Therefore, if rural people and people living within urban centres are to get out of poverty, cooperative movement should be encouraged and supported by government and other people or institutions of concern. To buttress this, [57] reported that members experience better household income (62\%) than non-members (20\%). Similarly, [55] noted that members of cooperatives acquired more assets than nonmembers. To conclude, a scholar work indicated that cooperative leads to rise in domestic assets with a positive correlation between domestic assets and income [50]. In can be inferred from the reviewed literature that, cooperative societies are significant for the development of people and their community no matter where they are located.

\section{METHODS}

The combination of qualitative and quantitative techniques known as mixed methods was employed alongside with experimental survey design for this study. The mixed method is a blending of both qualitative and quantitative techniques of data gathering and analysis to complement for the weaknesses of the two [54]. In light of the mixed methods approach, for an assessment to be meaningful the adoption of both quantitative and qualitative research designs are imperative. This school of thought believes that there are data that cannot be obtained with the use of only one of the methods [47]. The study adopted the qualitative method of data collection for the reason that the method proved suitable for effectively assessing the effect of cooperative societies on their members. Scholars who extol the virtues for the use of the method are of the view that it is an effective method for impact assessment which determines the phases through which conclusions are reached [12]. With the use of qualitative research method, the cooperative members who are farmers were approached with a questionnaire on how the community and their lives have been affected by the cooperative. Key informants who the researchers believed had important information relating to this study were also contacted including the Badu BACCSOD manager, Board of directors and some prominent people in the community of study.
Experimental design is also known as hypothesis-testing research design which is a design by which the researcher tests the hypotheses of causal relationships between variables [29], [30]. According to him there are two forms of experimental design: the formal and the informal experimental designs. He emphasized that the informal experimental design takes into account before and after without a control design. For this study, the design was therefore implemented to examine the before and after existence of the cooperative and its effect on the livelihood of farmers in the study area.

\section{A. Sample and sampling techniques}

The target sample was selected from a population of farmers in the study area who operated savings accounts with the cooperative of study. The convenience and random sampling methods were employed for the data collection. The convenience sampling method was used because of the asymmetrically dispersed distribution of farmers at the study area [9]. To begin, five (5) out of seven (7) sections of the town together with five (5) out of twenty (20) villages were purposively selected for the study. The selection of these study sites was informed by the fact that they were more actively engaged with the community bank to access loan facilities for their productive ventures. In total 200 farmers accepted to participate in the study. Both a questionnaire and an interview schedule were used because the respondents were both literate and illiterate farmers. 200 questionnaires and interview schedules were distributed to members of the cooperative society, who as well had owned farms in the study area in order to gather information from them for the analysis. In all, 30 and 13 questions were assigned to the farmers and the cooperative workers respectively. The questions captured the socio -demographic features of the farmers; cooperative membership profile; effects and benefits of the cooperative to farmers; categories of farmers the cooperative assisted; and cooperative roles in community development. The questionnaire was made up of both closed and open-ended questions. Pertaining to the closed-ended questionnaires, a five-point Likert scale was used (very high, coded as 1 , high $=2$, moderate $=3$, low $=4$, very low $=5$ ) . Secondary data was gathered from BACCSOD, Badu branch and used in the analysis to support the primary data.

\section{B. Study variables for analysis}

The interest rates of the cooperative and the number of people who demanded for loans for a period of five years starting from 2011 to 2015 constituted the main variables for the study. This was to help the researchers to understand the extent to which the cooperative was empowering the farmers of the area with abilities to meet their daily needs. Empowerment was measured in terms of the respondents' level of satisfaction with their farm outputs, their ability to acquire farms inputs and implements such as fertilizers, herbicides, insecticides cutlasses, knapsack sprayers etc. Respondents were asked to express their views on how they perceived their farm outputs and their livelihood before and after joining the cooperative society and accessed loan facilities to engage in productive agricultural activities. 


\section{Data analysis}

For the purpose of this research, data collected from the farmers (primary data) was analysed using the SPSS version 20 software. Data collected were entered into software for analysis after thorough cleaning was performed to discover and remove errors. The main analytical tools used were descriptive statistics and inferential statistics (paired samples T-Test; chi-square analysis and correlation analysis).

\section{Discussion and Findings}

TABLE 1: SOCIO-DEMOGRAPHIC CHARACTERISTICS OF RESPONDENTS

\begin{tabular}{llll}
\hline Variables & Categories & \multicolumn{2}{l}{$\begin{array}{l}\text { Related activities } \\
\text { responses }\end{array}$} \\
\cline { 3 - 4 } & & Freq. & $\%$ \\
\hline Gender & Male & 100 & 50 \\
& Female & 100 & 50 \\
Educational level & Primary & 45 & 22.5 \\
& JHS & 58 & 29.0 \\
& Secondary/SHS & 72 & 36.0 \\
Age & Tertiary & 14 & 7.0 \\
& 18- 25 years & 27 & 13.5 \\
& 26- 33 years & 48 & 24.0 \\
& 34- 41years & 54 & 27.0 \\
& 42- 49 years & 45 & 22.5 \\
& 50- 57 years & 16 & 8.0 \\
& 58- 65 years & 6 & 3.0 \\
Marital status & 66yrs and above & 4 & 2.0 \\
& Single & 61 & 30.5 \\
& Married & 118 & 59.0 \\
& Divorced & 12 & 6.0 \\
& Widowed & 9 & 4.5 \\
Occupation & Farming only & 92 & 46.0 \\
& Farming and other(s) & 108 & 54.0 \\
\hline & & &
\end{tabular}

The illustration on table 1 above, depicts that half $(50 \%)$ of the respondents are males and the other half (50\%) females. They were drawn in the ratio of 1:1 to enable the researchers obtain balance information from both sex respondents. The study denoted that greater number of respondents had attained Senior High School education representing 36\% as their highest educational qualification. This imply that many of them after their West Africa Certificate Examination (WACE) either could not pass or lacked financial support to continue. This was followed by respondents who had attained JHS education representing 29\%, Primary School was $22.5 \%$, Tertiary $7 \%$ and lastly, $5.5 \%$ represents those with nonformal education background and some others who had never been to school.

The ages of respondents interviewed reflected a high rate of economically active population. Out of a total of 200 people interviewed, 27\%of the respondent's ages were within the range of $34-41$ years. Followed by the age category 26 - 33years representing 24\%, 42 - 49years representing $22.5 \%, 18$ - 25years representing $13.5 \%, 50-$ 57 years representing $8 \%, 58-65$ years representing $3 \%$ and lastly 66years and above representing $2 \%$ of the total respondents. Out of total of these respondents, $59 \%$ of them were married, followed by $30.5 \%$ bachelors and spinsters, $6 \%$ divorced and lastly $4.5 \%$ windowed.

Consequently, a majority (54\%) of the respondents said that though farming was their main occupation, they were also into small businesses and other works. Notwithstanding that, $46 \%$ of them said they rely solely on farming their main occupation.

\section{E. Benefits/effects of cooperative to farmers:}

TABLE 2: FREQUENCY DISTRIBUTION FOR FARMERS' PERCEPTION ABOUT THE CO-OP INTEREST RATE BEFORE AND AFTER THEY BECAME MEMBERS

\begin{tabular}{lcccc}
\hline Response & \multicolumn{4}{c}{ Frequency } \\
& Before & $\begin{array}{c}\text { Percent } \\
(\%)\end{array}$ & After & $\begin{array}{c}\text { Percent } \\
(\%)\end{array}$ \\
\cline { 2 - 5 } & 8 & 4.0 & 11 & 5.5 \\
Very high & 13 & 6.5 & 27 & 13.5 \\
High & 91 & 45.5 & 129 & 64.5 \\
Moderate & 64 & 32.0 & 28 & 14.0 \\
Low & 24 & 12.0 & 5 & 2.5 \\
Very low & 200 & 100.0 & 200 & 100.0 \\
\hline Total & & & & \\
\hline
\end{tabular}

The descriptive statistics in table 2 above portrays that, almost half of the farmers (91 out of 200) representing $45.5 \%$ were of the view that the interest rate of the cooperative was relatively moderate before they became members. This is followed by $32 \%, 12 \%, 6.5 \%$ and $4 \%$ of the respondents who emphasised that the loan interest rate of the cooperative was low, very low, high and very high respectively before they also became members. Adding to that, more than half of the respondents (129 out of 200) representing $64.5 \%$ were of the view that, looking at the current economic situation and hence comparing the loan interest rate of the cooperative to that of other financial institutions, the cooperative interest rate after they became members was still moderate. Meanwhile 14\%, $13.5 \%, 5.5 \%$ and $2.5 \%$ of the respondents noted that the society's interest rate after they became members was low, high, very low and very high respectively. It can be inferred that the interest rate of the cooperative was affordable to farmers and possibly motivate them to demand loans for their productive or entrepreneurial ventures.

\section{F. Interest rate before against interest rate after farmers' membership:}

TABLE 3: MEAN COMPARISON OF INTEREST RATE BEFORE AND AFTER COOPERATIVE MEMBERSHIP OF FARMERS

\begin{tabular}{llc}
\hline Variable & Paired Differences
\end{tabular}

\begin{tabular}{lcccccc}
\hline & Mean & Std. & $\begin{array}{l}\text { Std. } \\
\text { Error } \\
\text { Mean }\end{array}$ & \multicolumn{2}{c}{$\begin{array}{l}\text { 95\% Confidence } \\
\text { Interval of the } \\
\text { Difference }\end{array}$} & \\
& & & & $\begin{array}{l}\text { Lower } \\
\text { Upper }\end{array}$ & \\
$\begin{array}{l}\text { Rate } \\
\text { before \& } \\
\text { rate after }\end{array}$ & 0.47 & 0.75 & 0.05 & 0.365 & 0.575 & 0.0 \\
\hline Correlation 0.62 at Sig. 0.00 & & & & & & \\
\hline
\end{tabular}


A further computation of farmers views on the cooperative interest rate before and after their membership indicates that the means of the loan interest rate before and after cooperative membership of respondents were 3.42 and 2.95. This clearly shows that there was a difference between the interest rate of the cooperative before the respondents became members and the interest rate after the respondents became members of the cooperative. The mean (3.42) of the responses about the cooperative interest rate before respondents became members of the society shows that, the interest rate was between low and moderate, while that of the mean (2.95) of the responses about the cooperative interest rate after respondents joined the society was also between high and moderate.

A significantly positive correlation $(r=0.62,0.000<0.05)$ between the cooperative's loan interests rate with respect to time was recorded. This means that the interest rate of the cooperative increases with time.

From table 3 a significant $(0.00<0.05)$ mean $(0.47)$ difference between the means of the responses about the interest rate before $($ mean $=3.42)$ and after $($ mean $=2.95)$ farmers membership. Implying that though comparatively interest rate must have been low at every point in time as compared to the industrial rate, the rate before respondents' membership and that of the rate after their membership were different.

\section{G. Farms outputs before receiving a loan}

TABLE 4: LEVEL OF SATISFACTION OF FARM OUTPUT BEFORE AND AFTER ACCESSING LOAN FROM THE CO-OP

\begin{tabular}{lcccc}
\hline Response & \multicolumn{4}{c}{ Frequency } \\
\hline & Before & $\begin{array}{c}\text { Percent } \\
(\%)\end{array}$ & After & $\begin{array}{c}\text { Percent } \\
(\%)\end{array}$ \\
\cline { 2 - 5 } very & 29 & 14.5 & 3 & 1.5 \\
dissatisfied & 42 & 21 & 3 & 1.5 \\
Dissatisfied & 14 & 7 & 15 & 7.5 \\
Neutral & 6 & 3 & 47 & 23.5 \\
Satisfied & 0 & 0 & 23 & 11.5 \\
Very satisfied & 109 & 54.5 & 109 & 54.5 \\
Not sure & 200 & 100 & 200 & 100 \\
\hline Total & & & &
\end{tabular}

The illustration on table 4 above depicts that more than half of the respondents representing $54.5 \%$ of the total farmers assumed a neutral position for a reason that they had never applied for loan from the cooperative before the survey. Meanwhile $21 \%$ of the respondents said they were dissatisfied with their farm produce before they took loan from the cooperative; whereas $14.5 \%$ of them were totally dissatisfied, $3 \%$ were rather satisfied with their farm outputs before they joined the society. Consequently, $7 \%$ of the respondents thought otherwise. According to them, they had not been keeping record of their farm outputs. The illustration also shows that no respondents were very satisfied with their farm output before receiving loan from the society. On the other hand, $23.5 \%$ of the respondents emphasised that a satisfactory farm output was realised after the society granted loan to them. This was followed by $11.5 \%$ who recorded a very satisfactory farm outputs after receiving loan facility. Notwithstanding that, $1.5 \%$ and another $1.5 \%$ of the respondents indicated that they were dissatisfied and very dissatisfied respectfully with their farms outputs even after receiving loan. Consequently, $7 \%$ of the respondents did not declare their stand on this issue.

TABLE5: MEAN COMPARISON EFFECT OF INTEREST RATE BEFORE AND AFTER COOPERATIVE MEMBERSHIP OF FARMERS ON FARM OUTPUT

\begin{tabular}{|c|c|c|c|c|c|c|}
\hline Variables & \multicolumn{5}{|c|}{ Paired Differences } & Sig. \\
\hline & \multirow[t]{2}{*}{ Mean } & \multirow[t]{2}{*}{ Std. } & \multirow[t]{2}{*}{$\begin{array}{c}\text { Std. } \\
\text { Error } \\
\text { Mean }\end{array}$} & \multicolumn{2}{|c|}{$\begin{array}{l}95 \% \text { Confidence } \\
\text { Interval of the } \\
\text { Difference }\end{array}$} & \\
\hline Before & & & & Lower & Upper & \\
\hline $\begin{array}{l}\& \\
\text { After }\end{array}$ & 2.03 & 1.82 & 0.129 & 1.776 & 2.284 & 0.00 \\
\hline
\end{tabular}

Respondents views about their farm's outputs were coded as; very dissatisfied $=1$, dissatisfied $=2$, neutral $=3$, satisfied $=4$, very satisfied $=5$ not sure $=6$. After computation, the mean of responses about their farms outputs before they obtained loan from the cooperative was 2.37 while that of the mean afterward was 4.40. The mean 2.37 implies that farmers were dissatisfied with their farm outputs before the obtained loan from the society, while that of 4.40 signifies that farmers were satisfied with their farms outputs after obtaining loan from the cooperative.

More so, the chi-square test of significant (0.00) confirms that there was a difference in the farm outputs of farmers before and after they cooperative granted loan to the farmers and hence their outputs after they took loans from the cooperative were far better than before. This means that the cooperative indirectly empowered farmers economically to be able to acquire farm inputs pay their wards' school fees, meet daily expenses, acquire assets and by extension develop their farms and businesses leading to their personal and community development at large.

\section{H. Respondents' wealth before membership}

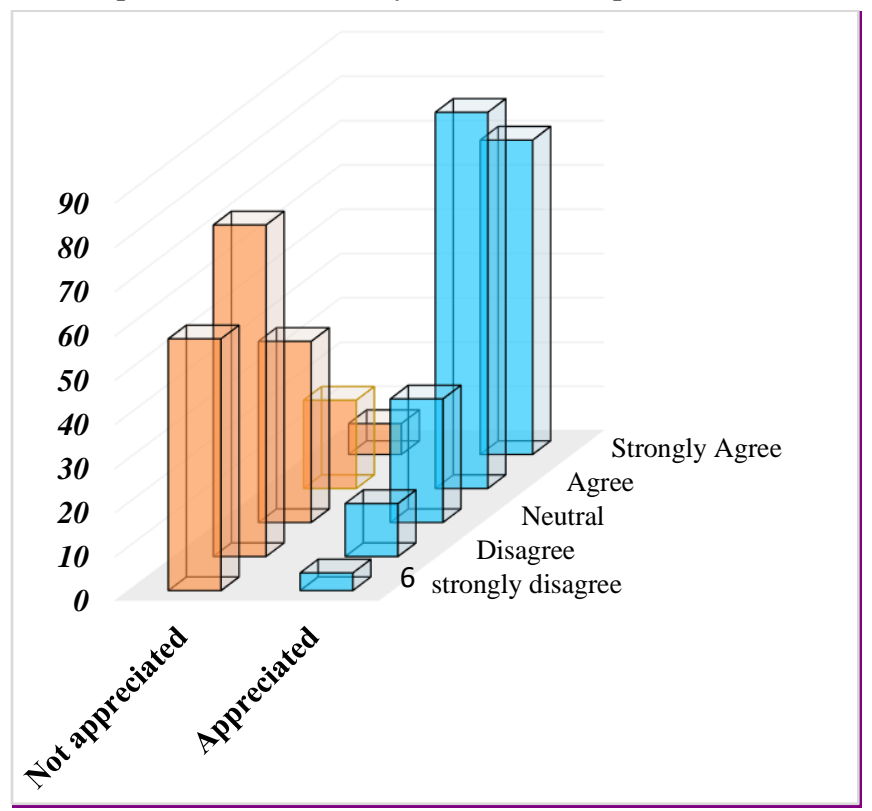

Figure1: Farmers' wealth status since they joined the co-operative society

From the illustration above, $37 \%$ of the farmers disagreed to the statement that, their wealth has not appreciated since they joined the cooperative, in the same way $29 \%$ of them 
strongly disagreed. On the other hand, $10 \%$ of the farmers affirm that there had not been any appreciation in their wealth since they become members with additional $4 \%$ strongly supporting them. Lastly, $20 \%$ of the farmers did not take a stand. The survey also depicts that $42 \%$ of the farmers agreed that their wealth appreciated after they joined the society with $36 \%$ more strongly supporting them. On the contrarily, $6 \%$ of the respondents disagreed, follow by $2 \%$ who also strongly disagreed. There was $14 \%$ of the respondents recorded who neither agreed nor disagreed to the statement. It could generally be inferred that farmers experienced an appreciation in their wealth since they joined the cooperative.

TABLE 6: MEAN COMPARISON OF VIEWS ON WEALTH APPRECIATION BEFORE AND AFTER JOINING THE COOPERATIVE

\begin{tabular}{|c|c|c|c|c|c|c|}
\hline \multirow[t]{2}{*}{ Variables } & \multicolumn{5}{|c|}{ Paired Differences } & \multirow[t]{2}{*}{ Sig. } \\
\hline & Mean & Std. & $\begin{array}{l}\text { Std. } \\
\text { Error } \\
\text { Mean }\end{array}$ & $\begin{array}{l}95 \% \mathrm{C} \\
\text { Interva } \\
\text { Differe } \\
\text { Lower }\end{array}$ & $\begin{array}{l}\text { dence } \\
\text { the } \\
\text { Upper }\end{array}$ & \\
\hline $\begin{array}{l}\text { Wealth never } \\
\text { appreciate } \\
\text { \&Wealth } \\
\text { appreciated } \\
\text { after }\end{array}$ & 1.2 & 1.59 & 1.42 & 0.11 & 0.95 & 0.00 \\
\hline
\end{tabular}

In table 6 , the mean of the general state of farmers' wealth before they became members of the society was 2.66 after the execution, while that of the mean after they became members was also 3.86. Meanwhile the followings were the coding made for the responses; strongly disagree $=1$, disagree $=2$, neutral $=3$, agree $=4$, strongly disagree $=5$. Therefore, to have a mean 2.66 as a description of the respondents' state of wealth before they associated with the cooperative means that farmers disagreed that their wealth never appreciated since they joined the society, while the mean of 3.86 indicates that respondents either agreed or strongly agreed that they were economically empowered only after they got registered as members.

The mean difference (1.20) designated in table 8 was found to be statistically significant $(0.00<0.05)$ between the wealth of farmers before and after they became members of the society. And hence it could be inferred that it was the society that helped its farmers to increase their wealth and could then comfortably take their responsibilities and acquire assets as well.

\section{Leverage on Community Development}

1. Community development rate before society membership;

TABLE 7: REPRESENTATION OF THE QUESTION; 'HOW WAS THE RATE OF DEVELOPMENT OF THE COMMUNITY BEFORE THE ESTABLISHMENT OF THE SOCIETY?'

\begin{tabular}{lcc}
\hline Response & Frequency & Percent $(\%)$ \\
\hline very fast & 2 & 1 \\
Fast & 28 & 14 \\
Quite fast & 73 & 36.5 \\
Slow & 67 & 33.5 \\
very slow & 14 & 7 \\
Not sure & 16 & 8 \\
\hline Total & 200 & 100 \\
\hline
\end{tabular}

The distribution of the respondents' views about the rate of development of the community before the formation of the cooperative in table 7 above shows that $36.5 \%, 33.5 \%, 14 \%$ and $7 \%$ of the respondents saw the development rate of the community by then to be quiet fast, slow, fast and very slow respectively. Meanwhile $1 \%$ of the respondents were of the view that, the development rate by then was very fast and lastly $8 \%$ of the respondents were neutral.

2. Community development rate since the cooperative establishment;

TABLE8: FREQUENCY DISTRIBUTION REPRESENTING THE QUESTION; 'HOW IS THE RATE OF DEVELOPMENT OF THE COMMUNITY, SINCE THE SOCIETY CAME TO FORMATION?'

\begin{tabular}{lcc}
\hline Response & Frequency & Percent $(\%)$ \\
\hline very fast & 65 & 32.5 \\
Fast & 88 & 44 \\
Quit fast & 40 & 20 \\
Slow & 1 & 0.5 \\
Very slow & 0 & 0 \\
Not sure & 6 & 3 \\
\hline Total & 200 & 100 \\
\hline
\end{tabular}

In table 8 above $20 \%, 44 \%$ and $32.5 \%$ of the respondents were of the opinion that, the formation of the society in the community resulted in it developing at quiet a fast rate, fast rate and very fast rate respectively. Whereas only one respondent also said that, the community was still developing at a slow rate even with the establishment of the society, 3\% of them thought otherwise. Generally, $76.5 \%$ of the total respondents were of the opinion that, the presence of the cooperative in the community positively impacts its development.

TABLE 9: MEAN COMPARISON OF VIEWS ON THE COMMUNITY RATE OF DEVELOPMENT BEFORE AND AFTER THE CO-OP ESTABLISHMENT

\begin{tabular}{llllll}
\hline Variables & \multicolumn{3}{l}{ Paired Differences } & Sig \\
\hline & Mean & Std. & $\begin{array}{c}\text { Std. } \\
\text { Error } \\
\text { Mean }\end{array}$ & $\begin{array}{l}\text { 95\% Confidence } \\
\text { Interval of } \\
\text { Difference } \\
\text { Lower Upper }\end{array}$ & \\
& & & & \\
$\begin{array}{l}\text { Community } \\
\text { development } \\
\text { rate before co- }\end{array}$ & & & & & 0.00 \\
$\begin{array}{l}\text { op } \\
\text { establishment } \\
\& \text { Community }\end{array}$ & 1.55 & 1.09 & 0.08 & 1.4 & 1.7 \\
$\begin{array}{l}\text { development } \\
\text { rate since co- } \\
\text { op } \\
\text { establishment }\end{array}$ & & & & & \\
\hline
\end{tabular}

Data was collected from respondents on their views about the rate of development of the community before and after the operation of the cooperative. This was to help the researchers determine whether the existence of the cooperative in the community was a catalyst for its development. The following was how the respondents' replies were coded; very fast $=1$, 
fast $=2$, quite fast $=3$, slow $=4$, very slow $=5$, not sure $=6$.

After the computation of the collected data, the mean of the replies of respondents shows that, the average rate of development of the community before the cooperative formation was 3.56 , while that of the average rate after the cooperative formation is 2.01 . The first mean (3.56) implies that the respondents' viewed the rate of development of the community before the operation of the cooperative to be between slow and quite fast. On the other hand, the second mean (2.01) indicates that the respondents saw the rate of development of the community to be fast after the inauguration of the cooperative. This is to say that the existence of the society in the town was fostering its development at a fast rate by way of helping residents to save and access loan as well.

Therefore, a statistically significant difference illustrated on table 9 was found between the two means, in that the existence of the cooperative in the community was identified as one of the driving forces for the town development and major source of financial empowerment for the people residing in it. It is therefore obvious that the cooperative society and the community development are asymptotic.

Test of null hypothesis $\left(H_{o}\right)$

The null hypothesis $\left(\mathrm{H}_{0}\right)$ for the study is 'cooperative societies do not promote communities' development' while the alternative hypothesis $\left(\mathrm{H}_{1}\right)$ also states 'cooperative societies promote communities' development'. In order for the researchers to gather empirical evidence to either accept or reject the null hypothesis, the researchers tailored a number of questions to the respondents. Below is a brief presentation of the results of the responses and how they contribute to the rejection or acceptance of the null hypothesis $\left(\mathrm{H}_{0}\right)$.

The illustration in table 9 depicts that $77 \%$ of the respondents emphasized that, the rate of development of the community before the cooperative formation was quite slow. While the replies of the respondents about the rate of development of the community after the cooperation of the society in table 10 shows that $76 \%$ of the responses implied that, after the formation of the cooperative the rate of development of the community was fast.

Henceforth a statistically significant $\quad(0.00<0.05)$ difference displayed in table 11 indicates that the mean of the responses about the rate of development of the town before and after the establishment of the society were not the same.

Consequently, it can be inferred that the cooperative society is one of the backbones for the development of the community. Hence the null hypothesis $\left(\mathrm{H}_{0}\right)$ is rejected in favor of the alternative hypothesis $\left(\mathrm{H}_{1}\right)$ which states that "cooperative societies promote communities' development".

\section{MAJOR FINDINGS}

The following were the main findings of the study:

a Paired Samples T-Test indicated that the existence of the cooperative in the community had a significant effect on the outputs of the farmers. That is farmers' farms outputs had increased due to the existence of the society.

It was realised that the wealth of the farmers had significantly improved as a result of the operation of the cooperative in the community. This was realised from a sample T-Test that was run using the responses of farmers on their wealth before and after the cooperative establishment.

The research unveiled that the cooperative society was gender sensitive; providing loans to both male and female peasant and commercial farmers irrespective of wherever they come from.

The findings further reveal that farmers could easily develop themselves (i.e. cultivate large farms, buy assets etc.) by simply applying for a loan from the society and using it profitably.

A paired sample T-Test run for the rate of development of the community before and after the formation of the cooperative indicated that the rate of development of the community appreciated considerably following the establishment of the society.

It was noted that apart from the financial leverage the cooperative offers to its clients, it does not provide farmers with farm implements and inputs at subsidised prices.

\section{CONCLUSION}

The conclusion that can be drawn from the finding is that cooperatives constitute the financial alternative for addressing poverty in rural areas where farmers are dominant. Financial cooperatives, in particular, are in no doubt the driving force of the rural economy, and for the building of inclusive economy for that matter. It significantly empowers farmers financially for a better livelihood as it emancipates them from poverty. Ultimately cooperatives have been versatile in meeting the essential financial needs of the rural dwellers by mobilising income and redistributing it through loans, thereby leveling the ground for financial equity and inclusion. Among other things, cooperatives empower farmers through capital building and loans which enables them to acquire farms inputs, implements and assets among others. There is virtually no substitute for cooperatives in the provision of support for rural finance availability that has sought to emancipate the financially marginalised rural populace from financial struggle; lifting them out of poverty as it acts as an economic silver bullet for salvaging them. It has the potential to transform the lifestyles of low-income earners especially in communities that have been undermined by the formal financial sector, if government introduces structured policy initiatives and programmes together with rigorous monitoring and supervision. Irrespective of banks, Notwithstanding the strong presence of investment houses and insurance companies operating in the same industry, financial cooperatives are still alive, active and vibrant in maintaining their market share with periodic expansion. There is no reason to undermine the role of cooperative societies in Ghana in any way. Therefore, cooperatives as they appear, may be the panacea for community development and poverty alleviation.

\section{POLICY RECOMMENDATIONS}

Many cooperatives should be established at various localities of the country particularly in the farming communities. Since cooperatives are more supportive to farmers. 
Financial Cooperatives operating in farming communities should in addition to giving of loans to farmers provide farms implements and inputs at subsidised prices to farmers.

Since cooperative societies are not for profit organizations, governments should subsidise their operational costs to motivate the establishment of many of them.

Government can intervene to protect the interest of cooperatives and farmers through innovative policies since agriculture and agribusiness continues to be the mainstay of most developing economies.

Chiefs and community leaders should be encouraged to release lands free of charge for the activities of cooperatives

\section{ACKNOWLEDGEMENT}

We wish to express our profound gratitude to the Almighty God for the gift of life. The openness and assistance provided by Badu St. Anthony parish priest, Rev. Fr. Stephen Kwasi Brenya, the Board of Directors of Badu BACCSOD Society Ltd, the manager; Mr. Yeboah Stanley, the project manager Mr. Okrah Kwadwo Victor, the cashiers; Miss Theresah Boahemaa and Mr. Dwomor Frederick, the account clerks; Miss Saawaa Mary and Miss Mansah Dorcas, all Susu collectors, all lovely customers (questionnaires respondents) and any other person who contributed to the success of this work are highly reckoned and appreciated.

\section{REFERENCES}

[1] Adebayo, S. C Evaluating strategy based on eight features of cooperative identity. (2010). Cooperative association as a tool for reural development and poverty reduction in Rwanda: A study of Ababuzamngambi ba kawa in Maraba sector. International Research Journals, 600 - 608.

[2] Adjei, J. K., \& Arun, T. (2009). Microfinance programmes and the poor: whom are they reaching? Evidence from Ghana. Brooks World Poverty Institute Working Paper Series, 7209, 265-291.

[3] Ahn, T. K., Isaac, M. \& Salmon. (2009). Coming and Going: Experiments on Endogenous Group Sizes for Excludable Public Goods. Journal of Public Economics. 93(1-2), 336-351.

[4] Alladadi, F. (2011). The contribution of agricultural cooperatives on poverty reduction: a case study of Marvdasht, Iran. Journal of American Science, 7(4), 22 - 25.

[5] Aniodoh, A. (2018). The Effect of Cooperative Professionals in National Development: A Study of Selected Cooperatives in Enugu State. Management, 7(3), 441 - 456.

[6] Aryeetey, E. (. (2005). Informal finance for private sector development in Sub-Saharan Africa. . Journal of Microfinance/ESR Review, 7(1), , 3

[7] Asiama, J. \&. (2007). Microfinance in Ghana, an overview. Economic Web Institute. Working Paper. Accra: Bank of Ghana.

[8] Bank, W. (2000). Financing Nigeria's Rural Micro and Small-Scale Enterprises. Washington D.C.: World Bank :Rural Development 2, Africa Region. Report No.: 19973-UNI, May 11.

[9] Baumgartner, T. S. (2002). Conducting and Reading Research in Health and Human Performance. New York: McGrawHill Companies.

[10] Chambo, S. \&. (2009). Global issues affecting cooperatives in Africa. Journal of Cooperative and Business Studies (JCBS), 1(1), 18-38.

[11] Cooperatives, D. O. (1990). (1990). History of Ghana Cooperatives. 1928-1985. Accra: Nsamankow Press.

[12] Copestake, J. D.-R. (2005). Monitoring the diversity of the poverty outreach and impact of microfinance: A comparision of methods using data from Peru. Development Policy Reviews, 23(6), 703-723.

[13] Develtere, P. P. (2008). ). Cooperating out of poverty. The renaissance of the African cooperative movement. Geneva: ILO.

[14] Develtere, P., Pollet, I., \& Wanyama, F. (2008). Cooperating out of poverty. The renaissance of the African cooperative movement. Geneva. Geneva: ILO.
[15] Develtere, P., Pollet, I., \& Wanyama, F.(Eds). (2008). Cooperating out of poverty: The renaissance of the African cooperative movement. International Labour Organisation. Geneva: ILO.

[16] Dubey, A. S. (2016). Cooperative societies for sustaining rural livelihood: A Case Study. . Indian Research Journal of Extension Education, 9(1), 43-46.

[17] Enete, A. (2008). Political and Genuine Cooperatives in Enugu State, Nigeria. In P. Develtere, Cooperating out of Poverty: The Renaissance of the African Cooperative Movement (pp. 208 -). Geneva: World Bank Institute.

[18] Estaban, J. \&. (2001). Collective action and the group size paradox. American political science review, 95(3), 663-672.

[19] Esteban, J., \& Ray, D. (2001). Collective Action and the Group Size Paradox. . The American Political Science Review, 95(3), , 663-672 Retrieved July 4, 2020, from www.jstor.org/stable/3118240.

[20] Falaiye, C. (2002). Assessing the impact of microcredit on rural Nigerian women. Guelph: University of Guelph.

[21] Ferguson, H. \&. (2011). Agricultural cooperatives and social empowerment of women: a Ugandan case study. Development in Practice, 21(3), 421-429.

[22] Gaboury, A., Mbwebwa Kalala, J. P., \& Développement international Desjardins (Corporation). (2002). The impact of savings and credit cooperatives in Burkina Faso. Lévis,: Lévis,Quebec: Développement international Desjardins.

[23] Ghosh, A. K. (2001). Impacts of dairy cooperative on rural income generation in Bangladesh. Journal of International Development and Cooperation, 8(1), 91-105.

[24] Henry, H., \& Schimmel, C. (2011). Cooperatives for people-centred rural development. Geneva: ILO.

[25] Iganiga, B. O. (2008). Much Ado about Nothing: The Case of the Nigerian Microfinance Policy Measures, Institutions and Operations Journal of Social Sciences, 17(2), 89-101.

[26] Jhingan, M. (2011). The economics of development and planning. New Delhi, Indica: Vrinda Publications.

[27] Kareem, R. A. (2012). The Impact of Co-operative Society on Capital Formation (A Case Study of Temidere Co-Operative and Thrift-Society, Ijebu-Ode, Ogun State, Nigeria). Global Journal of Science Frontier Research Agriculture and Veterinary sciences, 12(11), 16-28.

[28] Kothari, C. (2004). Research methodology: Methods and techniques. New Delhi: New Age International.

[29] Kumekpor, T. K. (2002). Research methods and techniques of social research. Accra: Son Life Press \& Service.

[30] Lafleur, M. (2005, February 16). Grocer Cooperative. Retrieved from AgECON Search: Research in Agricultural \& Applied Economics: http://www.cooperativegrocer.coop/articles/2009-01-21/modelcooperative-challenges.

[31] Lavlu, M. (2012). Agricultural productivity and food security in the developing world. Bangladesh Journal of Agricultural Economics, 35(12), 41-53.

[32] Liebrand, C. \&. (2014-16). Member Satisfaction with Their Cooperatives: Insights from Dairy Farmers. Lobleim: USDA.

[33] Ling, K. Charles \& Liebrand, Carolyn. (1998). A New Approach To Measuring Dairy Cooperative Performance," Research Reports 280010. Washington DC: United States Department of Agriculture, Rural Development.

[34] Lobleim, D. \&. (2014). Member Satisfaction with Their Cooperatives: Insights from Dairy Farmers. Washington: United States Department of Agriculture.

[35] Masuku, M. (2005). Cooperative studies, AEM 204 teaching manual. Luyengo, Swaziland: Faculty of Agriculture, University of Swaziland, Luyengo Campus.

[36] Mensah, F. A. (2016). Assessment of the contributions and challenges of credit union in Ghana: A case study of Techiman area Teachers Credit Union. Kumasi, Ghana: College of Social Science, http://ir.knust.edu.gh/xmlui/handle/123456789/8693.

[37] Michel, L. (2005). Evaluating strategy based on eight features of cooperative identity. $\quad$ Retrieved from http://www.cooperativegrocer.coop/articles/2009-01-21/modelcooperative-challenges

[38] Montgomery, H. and Weiss, J. (2005). Great Expectations: Microfinance and Poverty Reduction in Asia and Latin America. ADB Institute Research Paper Series. No. 63, i-30.

[39] Mrema, H. (2008). Uganda: Starting all over again. In P. P. Develtere, Cooperating out of poverty: The renaissance of the African cooperative movement (pp. 153-174). Dar es Salaam: ILO.

[40] Najamuddeena, G. A. (2012). Role of cooperative societies in community development in Sokoto metropolis, Sokoto state, Nigeria. Scientific Journal of Review, 1(3), 105-110. 
[41] [Nathan, O. F. (2004). (2004). Microfinance and poverty reduction in Uganda: Achievements and challenges. Economic Policy Research Centre. Kampala, Uganda: Economic Polixy Research Centre (EPRC).

[42] Ndiaye, F. ( 2005). Paper delivered at Expert Group Meeting on Poverty Eradication. Microfinance as a Strategy for Poverty Reduction in Africa (p. no page). Bangkok.

[43] Obeng, S. (2008). Rural banking in Ghana: Its impact on rural farmers: A case study of Abokobi rural area. Accra, Ghana: Samven's Research and Consultancy Unit.

[44] Oloyede, J. (2008). ] Oloyede, Informal financial sector, savings mobilization and rural development in Nigeria: Further evidence from Ekiti state of Nigeria . African Economic and Business Review, 6(1), 3563.

[45] Oluyombo, O. O. (2010). Assessing the Impact of Savings and Credit Cooperatives among Monthly Income Earners. Journal of Research in National Development, Vol. 8, No. 2b, 407-415.

[46] Onafowokan, O. (2012). The role of cooperative societies in rural finance: Evidence from Ogun State, Nigeria (Thesis). Leicester: De Monfort University.

[47] Oppon-Manu, I. (2004). Cooperatives and cooperative education in Ghana. Wisconscin, USA: University of Wisconscin.

[48] Ostrom, E. (2005). Understanding institutional diversity . New Jersey 393-432. New Jersey: Princeton University press.

[49] Ramotra, K. C. (2009). Impact of warana co-operative complex on standard of living in central warana basin of southern Maharashtra, India. Ethiopian Journal of Environmental Studies and Management, 2(3), 63-72.

[50] Ruhul, A. M., \& Mahin, U. M. (2014). Socio-Economic Impacts of Co operative Societies: An Empirical Study. SOCRATES: An International, Multi-lingual, Multi-disciplinary, Refereed (peer-reviewed), Indexed Scholarly journal, 2(2), 179-193.

[51] Sabatini, F., Modena, F., \& Tortia, E. (2014). (2014). Do cooperative enterprises create social trust? . Small Business Economics, 42(3), 621641.

[52] Samira, N. (2015). The Political Economy of Agricultural Cooperatives in Bosnia and Herzegovina: Towards a Sustainable Rural Development Model. Nepal: University of Trento School of Social Sciences Doctoral School.

[53] Saunders, M., Lewis, P. \& Thornhill, A. (2009). Research Methods for Business Students. 5th ed. England: Pearson Education Limited.

[54] Sharma, N. S. (2005). Impact Assessment of SACCOSs in Nepal's Hill Districts: Findings of an Action Research. Kathmandu: Centre for Microfinance (Pvt) Ltd.

[55] Shaw, J. (2004). World development, 32(7). Microenterprise occupation and poverty reduction in microfinance programs: evidence from Sri Lanka. , 1247-1264.

[56] Simkhada, N. (2004). Innovations in Nepal's microfinance sector and benefits for Asia-A case study of four savings and credit cooperative societies operating in the hills of Nepa. Sharing microfinance and Knowledge in South Asia (p. 15). Kathmandu: Centre for Microfinance(CMF) and the Foundation for Development Cooperation (FDC).

[57] Sizya, J. (2001). The role cooperatives play in poverty reduction in Tanzania. United Nations International Day for Eradication of Poverty. International Day of Cooperatives (p. 14). New York: UN DESA

[58] Tofael, A. (2009). The Development of Cooperative Sector of Bangladesh: Some Recommendations. Commilla: BARD.

[59] Tortia, E. C., Valentinov, V. L., \& Iliopoulos, C. (2013). Agricultura cooperatives. Journal of Entrepreneurial and Organizational Diversity, 2(1), 23-36

[60] Tsekpo, A. K. (2008). The cooperstive sector in Ghana: Small and big business. Cooperating out of poverty. The renaissance of the African cooperative movement, 179-212.

[61] Uddin, M. M. and Amin, R. . (2014). Socio-Economic Impacts of Cooperative Societies: An Empirical Study. Socrates. Vol.2 No. 2

[62] Verma, S. K. (2004). Cooperative Centenary in India. New Sector Magazine, 61., 1-2.

[63] Wanyama, F. O., Develtere, P., \& Pollet, I. . (2008). Encountering the evidence: cooperatives and poverty reduction in Africa. Journal of Cooperative studies, 16-27.

[64] Zeuli, K. \& Radel, J. (2005). Cooperatives as a community developmen strategy: Linking theory and practice. Journal of Regional Analysis and Policy, 35, 43-54

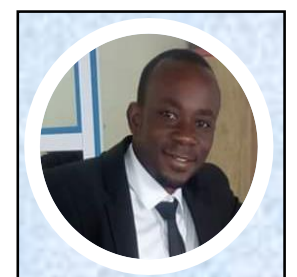

Ezekiel N. Seudib was born at Wa in the Uppe West Region of Ghana. He obtained Bachelor of Science Degree in Computing-withaccounting at the University for Development studies in Ghana, in the year 2015. He is currently an Accountant at BACCSOD Ltd (A local Bank), and a consultant \& data analysist at Universal Village Consult. He has led several data collection teams and teacher among others. His First paper published is titled "Chronic Absenteeism Fundamentals and Academic Performance - Case of Nante Islamic Junior High School of Kintampo South District in the Bono East Region of Ghana." Global Scientific journal, 2019. He has interest in qualitative and quantitative research in the banking and educational sectors.

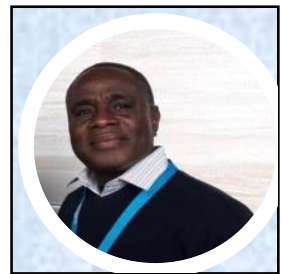

Issifu Amadu is Ghanaian by nationality. He is currently a lecturer at the university for Development Studies in Tamale. His working life has been punctuated with a series of intellectual activities, the most important of which has been, being a doctoral researcher at the prestigious Global Development Institute (GDI) at the University of Manchester in the United Kingdom. Dr Amadu has facilitated many postgraduate seminars in Human Resource Practice, Human Resource Management and Research Methods for Management. His research interests include: Public Policy and Management of the Public Sector, Human Resource Management and Development 